This is a pre-proof, uncorrected version. Please refer to, and only cite from, the final corrected

version available from Taylor and Francis:

http://www.tandfonline.com/doi/abs/10.1080/01916599.2012.747255

\title{
Sociability, Luxury and Sympathy: The Case of Archibald Campbell
}

\author{
PAUL SAGAR ${ }^{1}$ \\ King's College, Cambridge, United Kingdom
}

Summary: The eighteenth century moral philosopher Archibald Campbell is now largely forgotten, even to specialists in the Scottish Enlightenment. Yet his work is worth recovering both as part of the immediate reception of Bernard Mandeville and Francis Hutcheson's rival moral philosophies, and for better understanding the state of Scottish moral philosophy a decade before David Hume published his Treatise of Human Nature. This paper offers a reading of Campbell as deploying a specifically Epicurean philosophy that resists both the Augustinianism of Mandeville, and the Stoicism of Hutcheson. This leads him onto ground later claimed more conclusively by Hume, whilst helping us to better conceptualise the deployment and recovery of Hellenistic thought in the early modern period.

Keywords: Campbell, Mandeville, Hutcheson, Hume, Epicureanism, Augustinianism.

\section{Introduction}

The eighteenth century Scottish moral philosopher and theologian Archibald Campbell is now largely forgotten. With the exception of recent studies by Luigi Turco, James Moore, Anne Skoczylas and Christian Maurer, his work attracts little attention even from specialists in the Scottish Enlightenment, and a comprehensive understanding of his principle work, the Enquiry into the Original of Moral Virtue, remains outstanding. ${ }^{2}$

\footnotetext{
1Email: prs49@cam.ac.uk

${ }^{2}$ Luigi Turco, 'Sympathy and Moral Sense: 1725-40', British Journal for the History of Philosophy, 7 (1999), 79-101; James Moore, 'Utility and Humanity: The Quest for the Honestum in Cicero, Hutcheson and Hume', Utilitas, 14 (2002), 365-86; Anne Skoczylas, 'Archibald Campbell's Enquiry into the Original of Moral
} 
Although Turco has noted the apparent similarities between Campbell's arguments and those developed by David Hume, and Moore has located Campbell's moral philosophy inside an Epicurean framework opposed to the Stoicism of Francis Hutcheson, these represent only the beginnings of a complete account. More recently, Maurer has offered an illuminating reading of Campbell's views of self-love and their connection to moral self-cultivation as situated between the philosophies of Bernard Mandeville and Hutcheson. This paper will not succeed in providing a comprehensive appreciation of Campbell's thought, either, but it seeks to build on these previous studies by showing that Campbell's thought is worth recovering both as part of the immediate reception of Mandeville and Hutcheson, and in gaining a more adequate appreciation of the state of Scottish moral philosophy in the immediate period before the landmark publication of Hume's Treatise in 1739. In particular I endorse, but seek to extend, Maurer's reading of Campbell as navigating between the poles of Mandeville and Hutcheson: as adopting Epicurean ideas whilst rejecting both Augustinianism and Stoicism. I show how this positions Campbell in the eighteenth century debate regarding the natural sociability of mankind, involves him in the on-going dispute over the moral status of luxury, and leads him to develop an explicit theory of sympathy a generation before Hume's. I conclude by offering wider considerations on the use of Hellenistic thought in the early modern period, regarding both the method historians of ideas should adopt in this matter, and in turn how they should construct the histories they seek to write.

\section{Self-Love}


Thanks to Skoczylas we have a relatively complete picture of Campbell's life, including especially the fraudulent 1728 printing of his work by Alexander Innes under the title Arete-Logia, and Campbell's reclaiming of it with a revised edition in $1733 .{ }^{3}$ The 1728 version consisted of three separate treatises entitled 'An Enquiry into the Original of Moral Virtue', 'Moral Virtue Promotes Trade and Aggrandizes a Nation', and 'A Further Explication of the Foregoing Enquiry, \&c.'. The first two were levelled directly at Mandeville, the last - which reads like a subsequently-added, and somewhat rushed, appendix - attacked the arguments of Hutcheson. Campbell's 1733 edition retained the tripartite structure and titles but placed the account of trade at the back of the book, inserting the engagement with Hutcheson between Campbell's attacks on Mandeville. The discourse on trade received only minor modifications, but the other two were more substantially revised. In particular the first treatise in the 1733 edition focused on rejecting Hobbesian natural unsociability, attempting to show that despite the irreducibility of self-love in human motivation it did not follow - as Hobbes, Spinoza and Mandeville allegedly maintained - that 'Moral Virtue' reduced 'to a mere Chimera'. ${ }^{4}$ Instead the reality of moral distinctions could be maintained and shown to rest in 'the nature of things' (i.e. be objectively secured against debunking scepticism). In what follows, therefore, I offer an overview of Campbell's thought as it emerges from both editions. Yet in both the 1728 and 1733 incarnations Campbell's Enquiry is principally structured around a refutation of the arguments of Mandeville's Fable of the Bees. Although Campbell included substantial reflections on Hutcheson's 1725 Inquiry into the Original of Our Ideas of Beauty and Virtue, the primary target was always Mandeville,

\footnotetext{
3 Skoczylas, 'Presbyterian Orthodox', 78-83.

${ }^{4}$ Archibald Campbell, An Enquiry into the Original of Moral Virtue; Wherein it is shewn, (Against the Author of the Fable of the Bees, \&c.) that VIRTUE is founded in the Nature of Things, is unalterable, and eternal, and the great Means of private and publick HAPPINESS. WITH Some reflections on a late Book, intitled, An Enquiry into the Original of our Ideas of BEAUTY and VIRTUE, (Edinburgh, 1733), xvi-ii.
} 
with Hutcheson constituting a rival to Campbell's own counter-Mandevillean theory, to be confronted on technical issues of motivation and the nature of value once the main task was complete. Accordingly, I focus first on Campbell's rejection of Mandeville's provocative synthesis of Augustinian and Epicurean ideas.

A Dutch émigré and medical doctor living in London, Mandeville had issued a free-standing piece of doggerel verse in 1705 under the heading The Grumbling Hive: or, Knaves Turn'd Honest, which garnered little attention. Re-issued in 1714 as The Fable of the Bees, with 'Remarks' and a short essay 'An Enquiry into the Original of Moral Virtue', it continued to go largely unnoticed. However a second edition in 1723 with two provocative additions - 'An Essay on Charity and Charity Schools', and 'A Search into the Nature of Society' - almost immediately gained Mandeville notoriety as a libertine and promoter of vice. The Fable now enjoyed enormous succèss de scandale, particularly after presentation to the Grand Jury of Middlesex as a public nuisance. Unfairly derided as a scandalous libertine, Mandeville was actually a highly sophisticated thinker, the Fable a powerful synthesis of Augustinian and Epicurean ideas drawing on the $17^{\text {th }}$ century French Port Royal thinkers, Thomas Hobbes, and Pierre Bayle (whom Mandeville likely encountered in Rotterdam before studying at the University of Leiden). ${ }^{5}$ An overview of the argument and structure of the Fable is necessary for understanding Campbell's engagement with Mandeville, and the following serves as a schematic summary:

1. Mandeville operates with a starkly Augustinian view of humanity as 'mere fallen man'.6 Ours is a postlapsarian world ordered not for the temporal benefit of the sinful but as a vale of tears, salvation from which is possible only by the grace of

\footnotetext{
${ }^{5}$ John Robertson, The Case for the Enlightenment, (Cambridge, 2005), 261.

${ }^{6}$ Bernard Mandeville, The Fable of the Bees Volume 1, edited by F.B. Kaye, (Indianapolis, 1988), 348.
} 
God.7

2. Fallen man is 'solicitous of pleasing only himself': all human action is ultimately traceable to self-interest and self-gratifying pleasure seeking. ${ }^{8}$

3. Fallen man is a creature of pride, pained by the relative success of others. Yet he craves estimation in the mind of his peers. This mutual provocation of pride makes man naturally unsociable; he can be made sociable only by the artful manipulation of far-sighted politicians. ${ }^{9}$

4. True virtue consists in self-denial, and the suppression - but not the sublimation, nor overcoming - of desire. To be truly virtuous is to feel the pull of desire as a thirsty man craves fluid, and yet resist as far as possible despite the fact that to exist one must indulge. ${ }^{10}$

5. Any action that can be traced to passion forfeits its claim to true virtue; any action revealed as in some way motivated by passion cannot be truly virtuous. ${ }^{11}$

6. Complex systems of social virtue have, however, been developed by artful politicians to manipulate unsocial man into conditions of tolerable society. The social virtues are 'the offspring that flattery begot upon pride', and rest upon the manipulation of shame and honour to coax mutually odious men into tolerable conditions of society, engaging in substitute non-violent forms of status competition and domination. ${ }^{12}$ The social virtues are incompatible with true virtue because they can all be traced back to pride and self-interest.

7. Modern society, characterised by luxury, and the increasing economic prosperity the production of luxury entails, is riven a by central paradox: private vices (selfinterested pride and reflective glory-seeking in the minds of others by attaining social status, wealth and the ostentatious possession of luxury goods) generate

\footnotetext{
7 Mandeville, Fable Vol. 1, 166.

8 Mandeville, Fable Vol. 1, 41.

${ }_{9}$ Mandeville, Fable Vol. 1, remarks C, M, 0, R, and T passim.

10 Mandeville, Fable Vol. 1, 225-38.

11 Mandeville, Fable Vol. 1, 225-38.

12 Mandeville, Fable Vol. 1, pp. 41-58, 198-223. Mandeville himself does not use the term 'social' virtue, but unhelpfully discusses these under the blanket heading of 'virtue'. I introduce the term 'social' virtue to help clarify his thought.
} 
public benefits (the prosperity of polished, economically-flourishing societies erected on the supply and demand of luxury).13

8. Modern man faces an irreducible trade-off between (true) virtue and utility. Either we can be (truly) virtuous by living frugal, self-denying lives, abandoning the opulence, greatness and comfort of modern commercial society, or we embrace the latter and recognise it as bought at the price of vice and the erection of morally compromised forms of disingenuous social virtue founded on the manipulation of pride. ${ }^{14}$

As Turco has noted, Campbell attacked Mandeville's arguments but did so by endorsing the tenet that man is always driven by self-love. ${ }^{15}$ In adopting this position, Campbell conspicuously endorsed a position typically associated with Epicureanism. But what Campbell denied was that the psychological primacy of self-love entailed that conceptions of moral virtue founded in anything other than austere self-denial were necessarily fraudulent. Maurer observes that this allowed Campbell to develop a theory of moral self-cultivation conceptually ruled out by Mandeville. ${ }^{16}$ But before he could do so, Campbell first denied Mandeville's foundational contention: that man is naturally unsociable and has been made sociable only by the manipulations of far-sighted politicians using the bewitching engine of flattery upon pride.

Campbell claimed that, like Mandeville, he would consider man neither as Christian nor Jew, i.e. without appeal to divine revelation. But whereas Mandeville, in the first Fable, claimed that he dispensed with any appeal to providence in his account of how naturally unsociable humans became socialised, Campbell considered the

\footnotetext{
${ }^{13}$ Mandeville, Fable Vol. 1, passim, but for example 323-69. For discussions of Mandeville's views of luxury see Istvan Hont, 'The Early Enlightenment Debate on Commerce and Luxury', in The Cambridge History of Eighteenth Century Political Thought, edited by Mark Goldie and Robert Wokler, (Cambridge, 2006), 379418 (387-95); Christopher J. Berry, The Idea of Luxury: A Conceptual and Historical Investigation, (Cambridge, 1994), 126-34.

${ }^{14}$ Mandeville, Fable Vol. 1, passim, but for example 134-47.

15 Turco, 'Sympathy and Moral Sense', 89.

16 Maurer, 'Self-Cultivation', 21-5.
} 
evidence of God's plan so abundant in nature even the heathen philosophers of Greece and Rome discerned it. ${ }^{17}$ Accordingly, Campbell felt entitled to appeal to God's design and providence, whilst citing (at length, and somewhat implausibly) a wide variety of classical authors allegedly confirming his understanding of providence.

Campbell next identified self-love as the foundation of human psychology and motivation. "Tis very certain, that all Men have implanted in their Nature a Principle of Self-Love or Preservation, that irresistibly operates upon us in all Instances whatsoever, and is the great Cause, or the first Spring of all our several Motions and Actions, which Way forever they may happen to be directed'.18 But strikingly - given the Epicurean credentials of such an assertion - he immediately claimed that the basic principle of self-love guaranteed natural human sociability. All desires and motivations are but 'selflove diversified', and yet 'tis exceedingly manifest, that no Man living by himself in solitude, without all Commerce with the rest of Mankind, can enjoy himself with any Satisfaction, even though he should be well provided of all Things whatsoever that can be thought necessary to render a single Life every Way happy'.19 Precisely because of irreducible self-love, there is no principle in us as strong as the desire to engage in

\footnotetext{
17 Archibald Campbell, An Enquiry Into the Original of Moral Virtue, (Westminster, 1728), 2. Originally published as Alexander Innes, Arete-Logia, or, An Enquiry into the Original of Moral Virtue; Wherein The False Nations of Machiavel, Hobbes, Spinoza, and Mr. Bayle, as they are Collected and Digested by the Author of the Fable of the Bees, are Examin'd and Confuted; and the Eternal and Unalterable Nature and Obligation of MORAL VIRTUE is Stated and Vindicated. To which is prefix'd, A PREFATORY INTRODUCTION, In a LETTER to that Author (Westminster, 1728); Campbell Enquiry (1733), 3. In the second volume of The Fable of the Bees, Mandeville's long and intricate discussion of man's gradual socialization in dialogues 5 and 6 saw him back away from his earlier exclusion of revealed religion. He there attempted to integrate a complex account of the Christian religion and the necessity of revelation with a naturalistic story of man's gradual sociability: Bernard Mandeville, The Fable of the Bees Volume 2, edited by F.B. Kaye, (Indianapolis: 1988), 194-357. See also Robertson, Case for the Enlightenment, 274; E.J. Hundert, The Enlightenment's Fable: Bernard Mandeville and the Discovery of Society, (Cambridge: 1994), 62-96.

${ }^{18}$ Campbell, Enquiry (1728), 3-4; Enquiry (1733), 4-5.

${ }^{19}$ Campbell, Enquiry (1728), 4.
} 
society with others. ${ }^{20}$ As is typical in eighteenth century debates, Campbell's views on how human beings came to form societies directly influenced his stance on moral matters. ${ }^{21}$ Marrying a psychology of self-love to a principle of natural sociability laid the foundation for Campbell to situate his supervening moral philosophy between the scepticism of Mandeville and the affirmation of the reality of moral distinctions maintained by Hutcheson. As Maurer notes, the outcome is that 'As far as moral motivation is concerned, Campbell rejects the claim that our determination by self-love rules out the possibility for morally virtuous actions, thus contradicting an assumption made by both Hutcheson and Mandeville - albeit with contrary conclusions concerning our actual capacity to perform morally virtuous actions'. ${ }^{22}$

Campbell was aware 'others' (i.e. Hobbes) have claimed we associate only for the utility this brings, to secure 'Necessaries and Comforts of Life'. But this is an inadequate explanation. Although it is true that social living has utilitarian benefits, and many of the appetites we now find ourselves with could not be satisfied if we lived in solitude, utility alone cannot account for our psychological propensity to seek company:

[L] et a Man have in his single Lot all the Entertainments upon Earth, that one can possibly desire, yet those Things shall never be able to content his Mind, while he has not along with him some of his own Species, or has no Intercourse with other intelligent Beings: Which makes it pretty evident, that our Desire of Society must spring from somewhat else, than a Sense of our wanting the Assistance of others, to procure ourselves the Accommodations of Life. ${ }^{23}$

\footnotetext{
${ }^{20}$ Campbell, Enquiry (1733), 12-13.

${ }^{21}$ For an overview of the importance of sociability in eighteenth century moral discourse, see Istvan Hont, 'Commercial Society and Political Theory in the Eighteenth Century: The Problem of Authority in David Hume and Adam Smith', in Main Trends in Cultural History: Ten Essays, edited W. Melching and W. Velema, (Amsterdam, 1994), 54-94.

22 Maurer, 'Self-Cultivation', 20. On this matter, see especially Mandeville, Fable Vol. 2, 100-47.

23 Campbell, Enquiry (1728), 5-6.
} 
Furthermore, many of the 'Necessaries and Comforts' of life consist in having intercourse and commerce with others, receiving their good esteem and approval. Were we denied these things in a life of solitude we would be miserable, offending against our own principle of self-love driving us to seek society. ${ }^{24}$

In making these claims Campbell failed to understand, or simply ignored, the basic contention underlying Mandeville's argument for natural unsociability: that each man's self-love (primarily the passion of pride, at least in the first volume of the Fable) drove him to desire the esteem of others, but because esteem was a positional good men were in constant competition. Esteem required the imputed mental estimation of others, secured by over-awing them either physically or by some signalled recognition of status. Yet successful status-acquisition by one meant failure for individuals whose esteem was being extracted: man's pride drove him to glory over others but to hate it when they gloried over him. This guaranteed a mutual odiousness, a natural unsociability rectifiable only by artificially channelling impulses for domination into non-violent status competition, including especially systems of (false) virtue, politeness and honour.

Campbell bypassed this vision of natural unsociability, offering a thought experiment designed to demonstrate a natural sociability predicated on self-love. A man raised in solitude could have no desire for riches, luxury, pomp, or other things eliciting the esteem of others, and indeed would lack both the desire for such goods or for society generally. But what if two solitary men came into contact for the first time? In direct contrast to Mandeville's vision of mutually odious competitive status-seekers, Campbell claimed such individuals would immediately observe 'the Frame and

${ }^{24}$ Campbell, Enquiry (1728), 9; Enquiry (1733) 17-18. 
Structure of the other's Body to be the very same with that of his own'. This would have a mutually complementary result:

[T] his exact Resemblance cannot but warm their Breasts with very friendly Affections towards each other, and powerfully incline them to make up, each to his own Image, and to join Interest, each, as it were, with his Second Self. And when these two, who from the very outward Structure of their Body are mutually conciliated to one another, and feel a warm Propension to associate together, come further to understand that they can communicate their Thoughts distinctly to one another, and be reciprocally assisting in all their several Joys and Sorrows. This mightily strengthens their natural Propension to each other's society, and makes them affect living together with greater Ardency. From which it appears that a Disposition to Society is laid in the very Frame of human Nature. ${ }^{25}$

Born into families, experiencing repeat pleasurable interactions with others as we grow up, our natural desire to associate ensures that the more time we spend with others the more sociable we become. Accordingly, 'all Men from the Principle of Self-Love, must naturally fly Desarts and Solitudes, and cannot but passionately seek to join themselves with some or other of their own Kind to lead their Lives withal'. ${ }^{26}$ And we have further proof of natural sociability: that God gave us language is 'sufficient evidence' of His desire that we associate. ${ }^{27}$ Desire for honour and esteem did not generate a problem of natural unsociability, it was evidence for, a guarantee of, the exact opposite: 'It is much more impossible for the Desire of Esteem, to be separated from the Desire of Society, than for the Light and Heat of the Sun to be parted from one another'. ${ }^{28}$

In the 1733 edition Campbell scaled down his explicit arguments for natural sociability and inserted a long quotation from Aristotle's Nicomachean Ethics. ${ }^{29}$ This has

\footnotetext{
25 Campbell, Enquiry (1728), 7-9; Enquiry (1733), 14-17, 25.

${ }^{26}$ Campbell, Enquiry (1728), 9; Enquiry (1733), 18.

${ }^{27}$ Campbell, Enquiry (1728), 10-11; Enquiry (1733), 19-20.

${ }^{28}$ Campbell, Enquiry (1728), 15; Enquiry (1733), 54-55.

${ }^{29}$ Campbell, Enquiry (1733), 5-12.
} 
led Turco, and to a lesser degree M.A. Stewart, to suggest that Campbell's thought is crucially Aristotelian in its appeal to natural sociability. ${ }^{30}$ This is a mistake. As both scholars note, Campbell's reference is not to the account of zoon politikon in The Politics, but the discussion of friendship in the Ethics. Aristotle's text is made to stand-in for what had earlier been Campbell's own arguments for how self-love could be the foundation natural sociability. The use of Aristotle is cosmetic, with the purpose of deflecting criticism of Campbell's basically Epicurean position by presenting self-love as a respectable and non-controversial basis for natural sociability (more on this below). Campbell engineered an important break with Mandeville. Despite retaining the Epicurean maxim that all human action is driven by love of self, he jettisoned the Augustinian contention that man's self-love is primarily a species of competitive pride, making him psychologically odious and physically dangerous to others. ${ }^{31}$ Having refused the identity between self-love and pride, Campbell erected his own system aiming to refute and displace Mandeville. Asserting the uniformity of human nature across space and time, Campbell identified a cosmopolitan regard for the wellbeing of humanity as our 'natural' state. Each individual's desire for esteem ought to direct him to seek the esteem of all humanity by performing actions which would gratify every other person's self-love in a complementary cycle. ${ }^{32}$ Restrictions of this esteem-seeking to ever more local groupings - humanity without regard to God, particular nations, particular groups within nations - represented progressive steps away from man's

\footnotetext{
30 Turco, 'Sympathy and Moral Sense', 90-1; M.A. Stewart, 'The Scottish Enlightenment', in British Philosophy in the Age of Enlightenment, edited by Stuart Brown, (London, 1996), 274-308 (280).

31 Maurer, 'Self-Cultivation', 18-20.

32 The attentive reader will notice that Campbell seems to be drawing upon a Stoic idea of universality in moral matters, something found, for example, in Hutcheson's insistence on the universality of benevolence. This however is immediately offset by Campbell's centering the claim in the Epicurean tenet of self-love. A tension should rightly be noted here. But whether it is a tension in Campbell's thought, or in the interpretative framework used to analyse the use of Hellenistic philosophy by early modern authors, is an open question, to be considered (albeit indirectly) later in the paper.
} 
'natural' condition of universal sociability. ${ }^{33}$ In turn Campbell conspicuously defined 'vain-glory' as the restriction of our views to national groupings without regard to the esteem of humanity and God as a whole. Vain-glory was thus not - as Hobbes had infamously maintained - a natural passion of man making him dangerously unsociable. It was an unnatural aberration manifesting in unsociability, contrary to God's design and properly functioning human psychology. ${ }^{34}$

From this platform Campbell upended several central Mandevillean contentions. Pursuit of fame and glory is best achieved by undertaking actions promoting the selflove of others. As a consequence, 'all Men ought, according to Nature and Reason, to pursue after, not only Universal, but Eternal Fame and Glory'. ${ }^{35}$ It is a necessary truth of the relations of reality, comparable to the laws of geometry, that self-love and the seeking of esteem fit together in a mutually complementary relationship, allowing us to pursue fame and glory without being morally compromised. ${ }^{36}$ Furthermore Campbell's God was not the vengeful Augustinian deity found in the background to Mandeville's thought, abandoning postlapsarian man to a vale of tears intervening only to assist the elect few in efforts of self-denial. He was a God who, being likewise driven by self-love (a necessary principle for all rational beings), sought to promote our self-love. Self-love could thus be the foundation of authentic moral virtue founded in 'the nature of things' in precisely the way Mandeville denied. Not only were fame, glory and esteem authentically virtuous - a direct rejection of Mandeville's supposition that they were counterfeit virtue begat by flattery upon pride - but by vindicating self-love Campbell rejected Mandeville's claim that virtue must consist in self-denial. He joined Hutcheson

\footnotetext{
${ }^{33}$ Campbell, Enquiry (1733), 71-6.

${ }^{34}$ Campbell, Enquiry (1728), 17-24.

35 Campbell, Enquiry (1728), 29; Enquiry (1733), 86.

36 Campbell, Enquiry (1728), 61-2; Enquiry (1733), 53-6.
} 
in maintaining that 'Divine providence guarantees an ultimate harmony of the true interests of human agents and makes virtue the source of true happiness' ${ }^{37}$

\section{Luxury}

More could be said regarding Campbell's first treatise, especially his conception of God and providence, the extended use of quotations from classical sources (something largely unrepeated in the rest of the book), ${ }^{38}$ and his adaptation of the Epicurean idea of seeking moderate pleasures as the highest good whilst refusing to engage in 'monkish retreats'. ${ }^{39}$ Although some of Campbell's argumentative manoeuvres are unconvincing, he was a more able and interesting thinker than he has typically been given credit for. We have already seen that the backbone of Campbell's moral philosophy is a basically Epicurean psychology which resists the Augustinian components of Mandeville's system to issue in a principle of natural sociability and an affirmation of the reality of moral distinctions in the 'nature of things'. ${ }^{40}$ To further appreciate this central aspect of Campbell's thought we turn to the treatise 'Moral Virtue Promotes Trade and Aggrandizes a Nation'.

Campbell builds directly on his first treatise, and his argument is effectively a forerunner of Hume's 'Of Refinement in the Arts': that by relaxing the criteria of virtue away from austere self-denial it becomes inappropriate to label as vice what leads to

\footnotetext{
37 Maurer, 'Self-Cultivation', 20.

38 Moore, 'Utility and Humanity', 375-6, suggests that Campbell's extensive use of Cicero is of particular importance within the context of wider Scottish debates on the foundations of morality and the (non)coincidence of utility and virtue.

${ }^{39}$ Campbell, Enquiry (1728), 67-70. Another Scottish thinker who derided 'monkish' virtues was, of course, David Hume. See David Hume, A Treatise of Human Nature, edited by David Fate Norton and Mary J. Norton, (Oxford, 2007), 194, 367-86.

40 Accordingly, this paper strongly rejects Skoczylas's claim that Campbell was an orthodox Calvinist. His anti-Augustinian views put him firmly against the Calvinist mainstream, something the Kirk readily recognised when it summoned him before the Committee for Purity of Doctrine to question the compatibility of his moral philosophy with Presbyterian orthodoxy.
} 
public good. ${ }^{41}$ Full-scale analysis of Campbell's writings on commerce would require extensive consideration of the wider debates concerning nascent-political economy and luxury in early eighteenth century Scotland and beyond, so cannot be attempted here. But we can usefully focus on Campbell's discussion of luxury and how he extends his critique of Mandeville by again rejecting the Dutchman's underlying Augustinianism. As Istvan Hont has noted of Saint Lambert's 1762 luxury article in the Encylopédie, 'luxury was not merely an economic phenomenon, but the central moral and political issue of modernity'. ${ }^{42}$ What was true in 1762 was so in the 1720 s and 1730 s. In addressing the question of luxury Campbell was intervening in much more than a debate about the logic of commerce.

Mandeville's definition of luxury constituted the primary point of confrontation. According to the Dutchman, anything not immediately necessary to man's subsistence as a living creature was luxury. Yet this immediately generated trouble, insofar as even the most basic improvements to life made by rugged savages qualified: 'This definition every body will say is too rigorous; I am of the same Opinion; but if we abate one Inch of this Severity, I am afraid we shan't know where to stop'. ${ }^{43}$ Campbell by contrast set out to show that 'we may very well abate a good many Inches of this Severity, and yet know where to stop, so as not to go beyond the Nature of Things'. ${ }^{44}$ This he achieved not by denying that 'luxury' was inherently vicious (in this he agreed with Mandeville), but by placing luxury within a much narrower remit.

Luxury could not be construed simply in reference to pleasure. As the satisfaction of a great many of life's basic necessities, such as eating and drinking is

\footnotetext{
${ }^{41}$ Hume, Treatise, 182-4.

42 Istvan Hont, 'The Early Enlightenment Debate', 379.

43 Mandeville, Fable Vol. 1, 107.

${ }^{44}$ Campbell, Enquiry (1728), 103.
} 
accompanied by pleasure, any definition must specify more to avoid falling into absurdity. Campbell thereby freed essential argumentative space. If pleasure was not synonymous with luxury, a great many things we take pleasure in need not be counted luxury. This yielded the result that although our self-love frequently drives us to seek pleasure these need not necessarily be classed as luxuries, i.e. instances of vice. ${ }^{45}$ Having freed this conceptual space, Campbell moved to supplement it with a direct appeal to the nature of God:

But perhaps it will be alleged, that the Author of Nature has forbid us to taste any other Satisfactions, but what we feel in relieving our Hunger and Thirst, and in perpetuating our Species. Indeed, if this can be made appear, I shall own, that all other Pleasures are Vicious and Luxurious. But I am well persuaded, there is no Man who knows any Thing of the Nature of God, who will imagine, that any such Prohibition is laid upon Mankind by a Good and Beneficent Deity. ${ }^{46}$

Our experience of everyday life, such as gazing on God's creations and taking pleasure in appreciating their beauty, constitutes evidence that God intends us to take pleasure in living above bare necessity. There is no vice - and hence no luxury - in enjoying the pleasures God put in the world and made it inevitable for us to partake in. The consequence is clear: 'every Thing that is not absolutely necessary to keep a Man alive, can not with any the least shew of Reason or good Sense be counted Luxury'.47 Mere artifice and improvement do not qualify either, as there is nothing inherently vicious in such activities. God clearly wished us to engage in improving our situations, or he would have denied us the capacity to do so, and forbidden it. But 'where there is no Law, there is

\footnotetext{
${ }^{45}$ Campbell, Enquiry (1728), 102-6; Enquiry (1733), 472-7.

${ }^{46}$ Campbell, Enquiry (1728), 108; Enquiry (1733), 478-9.

${ }^{47}$ Campbell, Enquiry (1728), 110-11; Enquiry (1733), 481-2.
} 
no Transgression, no Luxury'. ${ }^{48}$ Conspicuously departing from Mandeville’s Augustinian outlook, Campbell declared:

Upon the whole I conclude, That the Author of Nature having so settled the Constitution of Things, that it is impossible for us not to perceive numberless other satisfactions, besides those that arise from such Objects as are absolutely necessary to keep us alive; we may all cheerfully indulge to ourselves those Gratifications without the least Degree of Vice or Luxury; and having our Breasts warmed with a grateful Sense of his unbounded Goodness, joyfully adore that Beneficent Being, who has poured out so much gladness all over the visible Creation, and given us the Skill and Power, above other Animals, to apply so many delightful Objects to our Entertainment. ${ }^{49}$

What, then, is luxury? It is not simply the taking of pleasure, but the taking of pleasure in activities which the 'nature of things' reveals as vicious, i.e. those which offend the selflove of our fellow men. Luxury remains vice, but understood within the specific framework of Campbell's theory:

And very manifestly, what ever Gratifications we pursue or entertain, so as therein to act Inconsistently with the Self-Love of God, and our Fellow-Men, these in our Case must be called Vice or Luxury, so far as we thereby give Offence, or do Mischief to those Rational Agents, among whom we are mixed, and unavoidably expose our selves to Neglect, Contempt, and Infamy. So that, in my Opinion, every Pursuit, every Pleasure that carries us beyond the Self-Love or Interest of those Beings to whom we are associated, or that inspires us with any Affection, or determines us to any Action that is contrary to their Good or Happiness, is Luxury. ${ }^{50}$

Campbell reinforces this conclusion by explicitly denying Mandeville's criteria of virtue as self-denial: 'I would beg to know what Authority our Author has to represent Moral Virtue as so austere a Thing, and under such horrid Gloom and Melancholy. Are his Notions founded on his own Fancy and Imagination, or does he take them from the

\footnotetext{
48 Campbell, Enquiry (1728), 112; Enquiry (1733), 483-4.

${ }^{49}$ Campbell, Enquiry (1728), 120; Enquiry (1733), 493.

50 Campbell, Enquiry (1728), 121-2; Enquiry (1733), 495.
} 
Nature of Things, or from the arbitrary Will of the supreme Being?'51 As well as directly rejecting Mandeville's Augustinian conception of God having abandoned us to a vale of tears, Campbell noted that if virtue consists in promoting the self-love of others then self-denial and retreat into ascetism must be vicious: such activity can only hurt and offend the self-love of those who desire our society. ${ }^{52}$ Campbell not only denied Mandeville's identification between pleasure and vice, he rejected the identity of selfdenial and virtue, thus freeing pleasure from the shackles of luxury. ${ }^{53}$

In turn it was almost trivially easy for Campbell to deny the central Mandevillean paradox of 'private vices, publick benefits'. Private vice for Campbell consisted in offending the self-love of others, hence could not promote public benefit. Insofar as luxury was coextensive with such vice the same applied, whilst activities which did not prejudice the self-love of others did not qualify as luxury, or vice. A great many commercial activities could be undertaken with impunity. It was true that a great and flourishing nation would be erected on a foundation of commerce and trade. But this foundation was not, as Mandeville supposed, morally compromised because of a necessary connection to luxury. Running the logic in the opposite direction generated exactly the result Campbell proclaimed: 'Moral Virtue promotes Trade and Aggrandizes a Nation'.

\section{Sympathy}

Campbell's third treatise consists of a lengthy, and somewhat rambling and relatively unfocused, engagement with Hutcheson's Inquiry. As noted, this final section reads -

\footnotetext{
51 Campbell, Enquiry (1728), 155; Enquiry (1733), 528-9.

52 Similar claims were made by Hume, Treatise, 190-211, 231-53, 367-86. See also David Hume, 'Of the Dignity and Meanness of Human Nature', and 'The Sceptic', in Essays Moral, Political and Literary, edited by Eugene F. Miller, (Indianapolis, 1985), 80-86, 159-80, and David Hume, 'Appendix 2: Of Self-Love', in An Enquiry Concerning The Principles of Morals, edited by Tom L. Beauchamp, (Oxford, 1998), 90-5. 53 Campbell, Enquiry (1728), 155-7; Enquiry (1733), 528-30.
} 
and in 1728 is effectively presented - as an appendix to the first two treatises, though the 1733 reworking better integrates the engagement with the main text. Campbell used a confrontation with Hutcheson to extend his own theory. This was necessary because Hutcheson's Stoic-Christian synthesis was a direct alternative to Campbell's account. Indeed it was a particularly threatening one, given that the loving deity which emerged from Hutcheson's deeply anti-Augustinian philosophy closely resembled that which Campbell had postulated in the first two parts of his Enquiry.

Hutcheson argued that God was benevolent and desired us to achieve happiness in this life, purposefully ordering the world and our relationships with others to that effect; a voluntarist who claimed God's having chosen to so-order the world was further evidence of his goodness. ${ }^{54}$ Like Campbell, Hutcheson saw that resisting Mandeville's Augustinian tenets and conclusions could be facilitated by direct appeal to an alternative conception of God. ${ }^{55}$ Where Hutcheson and Campbell came into crucial disagreement was in response to Mandeville's claim that any action motivated by selflove forfeited the status of authentic moral virtue.

Hutcheson agreed with Mandeville that if an action was motivated by self-love or self-interest it was morally compromised. Moral actions and their appreciation are entirely disinterested, thus saving ordinary practices of virtue from the fate Mandeville claimed. ${ }^{56}$ To achieve this Hutcheson developed a two-fold moral theory. First, we can be motivated to perform wholly other-regarding moral actions. Second, we can appreciate moral virtue as exhibited by others without ourselves reaping some private

\footnotetext{
${ }^{54}$ Francis Hutcheson, An Inquiry into the Original of Our Ideas of Beauty and Virtue, edited by Wolfgang Leidhold, (Indianapolis, 2004), 28-30, 197-8. See James Harris, 'Religion in Hutcheson's Moral Philosophy', Journal of the History of Philosophy, 46 (2008), 205-22, for an illuminating discussion of Hutcheson and religion.

${ }^{55}$ For Hutcheson as a critic of Mandeville, see Christopher Brooke, Philosophic Pride: Stoicism and Political Thought from Lipsius to Rousseau, (Princeton, N.J., 2012), 159-60.

${ }^{56}$ Hutcheson, Inquiry, 100.
} 
benefit, real or imagined. This was explained by the introduction of a 'moral sense', acting as both a faculty for the perception of virtue without reference to private interest, and also as the foundation for purely disinterested moral motivations. Hutcheson completed this account by identifying benevolence (i.e. disinterested love) as the key moral passion, which was both the source of our genuinely non self-regarding moral actions and the quality the moral sense approved of in others. Disinterested action was thus possible, and insofar as authentic virtue was founded in benevolence rather than self-denial our everyday moral practices were vindicated, the reality of moral distinctions secured against Mandeville’s debunking scepticism. ${ }^{57}$

Although Hutcheson encountered serious difficulties in establishing the philosophical coherence and psychological plausibility of his perceptual account which he attempted to defend, extend and refine in the 1728 An Essay on the Nature and Conduct of the Passions and Affections, with Illustrations on the Moral Sense ${ }^{58}$ - in his 1725 work he sought to turn the tables completely on Mandeville. Taking himself to have proved that in immediate interactions with other agents disinterested action is entirely possible, Hutcheson attempted to show that in another sense a virtuous life was in the best interest of virtuous agents themselves. Drawing on Stoic moral philosophy, and especially its reworking by The Third Earl of Shaftesbury, Hutcheson argued for a necessary connection between happiness and virtue which generated security from the vagaries of fortune along the lines of Stoic apatheia: 'so that while we are only intending the Good of others, we undesignedly promote our own greatest private Good'. ${ }^{59}$ Those concerned with their own self-love would not seek immediate personal gratification (as

\footnotetext{
57 Hutcheson, Inquiry, 89-90, 101-2, 116.

58 Francis Hutcheson, An Essay on the Nature and Conduct of the Passions and Affections, With Illustrations on the Moral Sense, edited by Aaron Garrett (Indianapolis, 2002). On the development of Hutcheson's ideas between these texts, see Harris, 'Religion in Hutcheson's Moral Philosophy'.

${ }^{59}$ Hutcheson, Inquiry, 99.
} 
Mandeville claimed), or further the self-love of others out of a sense of the gains to their own reciprocally-enhanced self-love (as Campbell claimed). They would instead seek the wholly disinterested promotion of the good of others out of non-self-referential benevolence, but which thanks to divine providence secured their own best happiness as an indirect product of virtuous living. ${ }^{60}$

This was a powerful challenge, rejecting both the Epicurean and the Augustinian components of Mandeville's psychology and attendant moral theory. Not only did God order our constitutions to enable us to act disinterestedly and thus virtuously, he also ensured that a reasonable degree of happiness could be expected in this life and without direct divine assistance. Campbell recognised that Hutcheson's account was by extension a direct challenge to his own philosophy: it offered an alternative method of resisting Mandeville, which likewise rejected the assumption of a vengeful Augustinian deity, but did so with a moral psychology which denied the primacy of self-love. In response Campbell set out to show that self-love must lie at the bottom of any intelligible theory of valuation and motivation. Hutcheson's repeated denial of this simply meant that the foundations of his Stoic project were rotten, and the attendant superstructure bound to fall. ${ }^{61}$

Campbell began his rejection by expanding his understanding of self-love, now claiming that it is predicated upon the basic operations of pain and pleasure. ${ }^{62}$ To this

\footnotetext{
${ }^{60}$ Hutcheson Inquiry, 99, 163. For an assessment of Hutcheson's Stoic commitments see Brooke, Philosophic Pride, 159-164; James Moore 'Hutcheson and Hume', in Hume and Hume's Connexions, edited by M.A. Stewart and John P. Wright, (Edinburgh, 1994), 22-57; 'The Eclectic Stoic, The Mitigated Skeptic, in New Essays on David Hume, edited by E. Mazza and E. Ronchetti (Milan, 2007), 133-69. But see also David Fate Norton, 'Hume and Hutcheson: The Question of Influence', in Oxford Studies in Early Modern Philosophy, edited by D. Garber and S. Nadler, six vols, (Oxford, 2005), II, 211-56.

${ }^{61}$ M.A. Stewart is accordingly mistaken in claiming that the disagreement between Hutcheson and Campbell was 'To some degree...a verbal dispute'. On the contrary, it was real and fundamental. Stewart, 'Scottish Enlightenment', 280.

62 Campbell, Enquiry (1728), 176-7; Enquiry (1733), 260-2.
} 
distinctively Epicurean thesis he added further impeccably Epicurean reflections: that we should not seek simply the most intense pleasures but those which are likely to be most sustainable and do not invite later pains, in the short-term selecting pains which prevent greater future pain or secure anticipated pleasure. ${ }^{63}$ Campbell then observed that the mind could be kept alive and sustained only by the body. The preservation of the body was thus desired by the mind, which accordingly approved of those pleasures which help keep the body in good condition. But to these recognisably Epicurean ideas he appended his distinctive conception of God. Like all rational agents God was moved by his own self-love, which harmonised with our own: He ordered our constitutions so that we take pleasure in many material processes that keep our minds alive in this world by supporting the body. But as God would also reward us in the next life, where our bodies cannot follow us, it follows that our highest pleasures are ultimately of the mind. The seeking of pleasure and avoiding of pain will therefore not degenerate into hedonistic libertinism of the sort attributed to a crude but common caricature of Epicureanism in the eighteenth century. ${ }^{64}$

For Campbell, any moral philosophy which did not have a foundation in self-love - i.e. the seeking of pleasure and the avoidance of pain - would be incapable of explaining two things: how we could come to value anything, and how we could come to be motivated to any moral action. We value that which gratifies our self-love, hence we are motivated to pursue that which is pleasurable and avoids pain insofar as this is the essence of self-love. It follows that vice and virtue are informed and supported by the basic hedonistic psychological framework Campbell developed. This leads him to claim (somewhat implausibly) that according to no less an authority than Socrates 'all our

\footnotetext{
${ }^{63}$ Campbell, Enquiry (1728), 206, 213; Enquiry (1733), 276-81.

${ }^{64}$ Campbell, Enquiry (1728), 206-9; Enquiry (1733), 282-300.
} 
Safety and Happiness depends upon the Good Choice we make of Pleasure and Pain; Which cannot be done unless we have some particular Science whereby to govern our Judgement in those Points'. This science of moral philosophy is simply that 'which shews...where Pleasure lies, and removes and keeps off that Darkness and Ignorance, whereby we are betray'd into Vicious Actions' ${ }^{65}$ Whatever Hutcheson contended, his 'occult quality' of a moral sense would ultimately have to be explainable with reference to self-love if it was to be psychologically, motivationally and philosophically intelligible. But if the moral sense was revealed as founded in self-love, Hutcheson forfeited any claim to have located an intrinsically disinterested foundation for morality, and his rival project must fail. ${ }^{66}$

Having established this basic contention, Campbell targeted Hutcheson's specific arguments for establishing the possibility of disinterested benevolence. It is worth pausing to consider in particular his attack on Hutcheson's claim that parents love their children from disinterested benevolence, and that we are all capable of feeling an analogous (if weaker) disinterested love for fellow humans who are not our offspring. Campbell rejected this by claiming that we love our children as extensions of ourselves. ${ }^{67}$ But recognising that this would not account for our attitudes towards nonrelations, Campbell developed what Turco has labelled a forerunner of Hume and Adam Smith's arguments for a mental capacity of sympathy. ${ }^{68}$

${ }^{65}$ Campbell, Enquiry (1728), 215, 217; Enquiry (1733), 300, 302.

${ }^{66}$ Campbell, Enquiry (1728), 228-30; Enquiry (1733), 320-2.

${ }^{67}$ Campbell, Enquiry (1728), 240-41; Enquiry (1733), 336-8.

${ }^{68}$ Turco, 'Sympathy and Moral Sense', 93. Turco also claims (correctly) that Campbell's account is essentially Hobbesian, not Humean. This generates an unresolved tension between the conclusions of his analysis of Campbell's account of sympathy and his opening claims regarding similarity to Hume and Smith. 
In fact Campbell's conception had less in common with that later proposed by Hume and Smith, and was primarily a development of Hobbes's account of pity. In the Leviathan Hobbes claimed that:

Griefe, for the Calamity of another, is PITTY; and ariseth from the imagination that the like calamity may befall himself; and therefore is called also COMPASSION, and in the phrase of this present time a FELLOW-FEELING: and therefore for Calamity arriving from great wickedness, the best men have the least Pitty; and for the same Calamity, those have least Pitty that think themselves least obnoxious to the same.69

Pity was simply a mechanism whereby we imagined ourselves into the situation of a suffering other and reacted as though their calamity were befalling us. This was famously attacked by Joseph Butler for not being able to explain why we pity our friends more than strangers, why pity and fear are not the same thing, why compassion is classed as a virtue, and why we pity those who suffer fates we are entirely secure from. ${ }^{70}$ Given that Hutcheson mounted similar claims in the Inquiry, it is highly likely Campbell was aware of such objections. ${ }^{71}$ His conception of sympathy sought to extend the Hobbesian account, taking it beyond its previously narrow confines but simultaneously retaining its foundation in the self-love of the individual observing agent.

Campbell's 'sympathy' extends beyond instances of witnessing the immediate pain or suffering of another, and is a process by which we imagine ourselves into various situations experienced by others which may be pleasurable or painful. It is thus a sophisticated Hobbism: the basic mechanism is extended beyond mere fear of

69 Thomas Hobbes, Leviathan, or the Matter, Forme, and Power of a Commonwealth Ecclesiastical and Civill, edited by Richard Tuck, revised student edition, (Cambridge, 2008), 43.

70 Joseph Butler, Fifteen Sermons Preached at the Rolls Chapel, edited by T.A. Roberts, (London, 1970), 4950.

${ }^{71}$ Turco claims that Hutcheson further extended his arguments against Hobbesian pity as a direct response to the developments of thinkers like Campbell and John Clarke of Hull. Turco, 'Sympathy and Moral Sense', 99-100. 
potential private harm or calamity, to encompass any emotive state another agent may be experiencing. This innovation built directly on Campbell's earlier arguments regarding our being drawn to those who have like constitutions, finding pleasure in the esteem gained from others. But Campbell's sympathy remained Hobbism because even when imagining ourselves into the situation of others it is our own self-love animating us in line with the relevant imagined pleasure or pain to ourselves. For Campbell this was simply a consequence of what he took to be a psychological truism: we could only value something, or be motivated to some action, in line with private pleasure or pain. Campbell thus consolidated the connection between natural sociability and self-love. Sympathy was an extended species of self-love, taking account of the feelings of others by imagining they were one's own. But his theory was therefore not a direct forerunner of Hume's. For Hume, sympathy was founded not in private self-love but arose from identifying with the pains or pleasures of another after inferring their sentimental state, being aware throughout that the pains and pleasures remained precisely those of another. Although sympathy meant the transformation of the 'idea' of another's sentimental state into an 'impression' which was itself a mirroring sentiment, the point was precisely that although one came to share to some degree the sentiment the other was feeling, one never lost sight of the fact that the other was feeling, and this was the primary and necessary source of one's own sentimental response. ${ }^{72}$

The language Campbell used to describe his concept of sympathy is striking, however, insofar as it does strongly prefigure that used by Hume:

Human Creatures might be compar'd to Musical Instruments that have Similar Chords, wherein it happens, that when one of these Chords is struck upon, all the Rest that are Unisons, receive the same Tremulous Motion which occasions the Same Sound, or are

${ }_{72}$ Hume, Treatise, 205-8, 237-8, 367-7. 
affected in the same Manner. And it appears, that the Great Author or Nature has design'd we should thus sympathize, or be thus affected with one another's Circumstances; For I see no other Reason that can be given, why the Inward Passions of the Mind express themselves so very distinctly in Human Countenances. ${ }^{73}$

A generation later, Hume would reach for precisely the same metaphor: 'As in strings equally wound up, the motion of one communicates itself to the rest; so all the affections readily pass from one person to another, and beget correspondent movements in every human creature'. ${ }^{74}$

Again supplementing his account with a direct appeal to God, Campbell took himself to have established a vital further component of his moral philosophy, now primed to displace Hutcheson's philosophy as well as Mandeville's. Campbell's sympathy allowed him to account for moral actions which were ostensibly disinterested, bringing within the purview of self-love those actions Hutcheson claimed for benevolence:

[T] his cannot but oblige One to admire the great Goodness of the Author of Nature, and his Fatherly Concern for the Happiness of Mankind, who has thus secur'd our Mutually assisting one another in all our Afflictions, not only from a Reciprocal Love, but from a tender Fellow-Feeling, or a generous Sympathy, whereby we are blended or knit together in the same common Lot, so as to take part in each other's Distress. ${ }^{75}$

Sympathy allowed Campbell to undercut Hutcheson's claim that men were capable of wholly disinterested benevolent actions, instead explaining these as the complex operations of self-love supplemented by processes of imagination. Of course, such was the extent of Campbell's sympathy that it became questionable as to whether it could really be maintained as a species of self-love after all. But taking the further step of

\footnotetext{
${ }^{73}$ Campbell, Enquiry (1728), 244-5; Enquiry (1733), 340-1.

74 Hume, Treatise, 368.

75 Campbell, Enquiry (1728), 288-9; Enquiry (1733) 394.
} 
disengaging sympathy from self-love whilst refusing Hutchesonian benevolence as the sole foundation of morality would have to wait for the innovations of Hume. What we can see, however, is that the development of sympathy in a basically Epicurean approach to moral philosophy had undergone important advances in Scottish theorising a decade before Hume published the Treatise. ${ }^{76}$

By constructing an account of human psychology as based irreducibly in selflove, claiming that no process of valuation or motivation was comprehensible without reference to an underlying pleasure-pain mechanism, and developing a sophisticated, but in crucial dimensions still essentially Hobbist, conception of pity he labelled 'sympathy', Campbell took himself to be able to comprehensively refute all of Hutcheson's contentions for a disinterested motivation to virtue and in each case reveal self-love as the hidden foundation. As with his attack on Mandeville, Campbell appealed to explicitly Epicurean concepts of human psychology and attendant moral philosophy, but jettisoned Augustinian notions of God and of men's relations to each other. In the process, the Stoic component of Hutcheson's alternative project of founding morality in disinterested benevolence was likewise rejected.

\section{Anti-Augustinian Epicureanism?}

The argument of this paper has so far been advanced by textual exegesis alone. But it is worth adding some further considerations, as well as indicating the significance of this reading beyond analysis of one largely forgotten and relatively minor thinker. Campbell's anti-Augustinian outlook emerges strongly from the text, but it may be wondered how this can be squared with the fact he was an ordained Presbyterian minister who subscribed to the Westminster Confessions. There is, however, no great

\footnotetext{
${ }^{76}$ On Hume's distancing himself from philosophies of self-love see Moore, 'Utility and Humanity', 379-86.
} 
mystery. For a bright and ambitious young man of Campbell's generation, the Kirk represented a clear and steady path of career advancement, indeed one Campbell walked very successfully. Tutelage under, and on-going friendship with, the controversial professor John Simson, indicates that Campbell's views on theological matters were likely to have been far from Calvinist orthodoxy from an early age. ${ }^{77}$ That Campbell later had to defend himself before the General Assembly's Committee for the Purity of Doctrine indicates that his contemporaries readily identified his heterodoxy. ${ }^{78}$

This carries an important upshot. In major studies of the development of $17^{\text {th }}$ and eighteenth century intellectual history, John Robertson and Pierre Force have argued that by the eighteenth century Augustinianism and Epicureanism became synthesised as complementary philosophical systems. Both emphasised self-love as man's driving passion, a resulting scepticism regarding human capacities to form societies out of natural affections alone, and an emphasis on the ironic and unintended but useful consequences emerging from the self-interested interactions of competitive individuals. Although both note that atheistical materialist Epicureanism was originally starkly opposed to Augustinian Christianity, an emphasis on man's being driven to seek his own pleasure, and explorations of how self-interested motivation could paradoxically lead to group-wide benefit, made for a convergence between these outlooks, thanks in particular to the French Port Royal thinkers of the $17^{\text {th }}$ century. ${ }^{79}$ As Force and Robertson correctly claim, Mandeville offers the clearest demonstration that

\footnotetext{
77 On Campbell's friendship with Simson, see Skoczylas, 'Presbyterian Orthodoxy', 72-5. As noted above, however, I reject Skoczlas's claim that Campbell was an orthodox Presbyterian.

78 Maurer, 'Self-Cultivation', 22-25.

${ }^{79}$ Pierre Force, Self-Interest Before Adam Smith: A Genealogy of Economic Science, (Cambridge, 2003), 4890; Robertson, Case for the Enlightenment, 124-46, 261-80. Both draw upon the account in Jean Lafond, 'Augustinisme et Epicurisme au xvii siècle', in L'Homme et son image: Morales et littérature de Montaigne à Mandeville, (Paris, 1996), 345-68.
} 
by the early eighteenth century the two traditions could be combined into a powerful philosophical outlook.

I do not wish to dispute that by the early eighteenth century Epicurean and Augustinian ideas could be so combined. But I present Campbell's work as a reminder that they did not have to be: their synthesis was no necessary or final process. What one took - or equally importantly, did not take - from Epicurean or Augustinian thought was itself an open question, decided by the judgement of thinkers engaged in live controversies. It was evident to even a minor thinker like Campbell, not amongst the first rank of philosophers in the reception of Mandeville, that these philosophical outlooks could be decoupled, using aspects of one to attack the other. Doing so provided resources for rebutting contemporary philosophical rivals, who were themselves adapting and modifying inherited ideas, but likewise sought to erect original systems of thought aiming to go beyond existing accounts. Doubt can in turn be cast upon Force's contention that by the eighteenth century those who opposed the AugustinianEpicurean synthesis of Mandeville found the materials to do so predominantly in a revived Stoicism. ${ }^{80}$ Force applies this reading to Adam Smith and Jean-Jacques Rousseau, but Campbell shows that Stoicism was not the only option for resisting the Mandevillean challenge. ${ }^{81}$ Given the Scottish context of Smith's writings, this is of significance for Force's thesis in particular.

Understanding Campbell as a thinker who draws upon Epicurean ideas to resist Augustinianism has further import the more we are drawn to the similarities between Campbell's project and that effected a generation later by Hume. Large differences

\footnotetext{
${ }^{80}$ Force, Self-Interest, 57-67.

${ }^{81}$ Robertson rejects Force's reading of Rousseau and Smith as neo-Stoic opponents of an AugustinianEpicurean synthesis as 'unconvincing'. I agree. Robertson, Case for the Enlightenment, 396.
} 
certainly exist between the two: not only Hume's considerably greater genius, but his wholesale abandonment of theistic premises, his much more ambiguous and complex stance on human sociability, his detailed conception of the role of artifice in moral distinctions, and his vastly more complex understanding of the foundations of morality. Nonetheless, Hume would follow Campbell onto basically the same ground insofar as he constructed a philosophy drawing on Epicurean ideas - especially the primacy of psychological pleasure-seeking and pain-avoidance, and the artificiality of aspects of human sociability - that resisted both the Augustinian of Mandeville and the ChristianStoic synthesis of Hutcheson, locating moral distinctions in human sentiment whilst nonetheless maintaining the reality of moral distinctions. ${ }^{82}$ Certainly this was ground Hume would make distinctively his own and develop in innovative ways. But 11 years before the publication of the Treatise of Human Nature, the basic materials Hume would bring to bear were already recognised as available, and put to use by Campbell. This is not to allege some crude line of 'influence' from one to the other. We do not know if Hume read Campbell, and even if he did it is unlikely the work and intellect of a thinker like Hume's can be usefully understood in terms of debts owed to the conceptually much weaker output of Campbell. I simply suggest that Campbell demonstrates that Hume was not the first to attempt to combine ideas in the way he did. The philosophical

\footnotetext{
82 For Hume's moral and political philosophy as drawing on Epicureanism, see James Moore, 'Hume and Hutcheson', 'The Eclectic Stoic'; Luigi Turco, 'Hutcheson and Hume in a Recent Polemic ', in Hume and Hume's Connexions, 79-101; Robertson, Case for the Enlightenment, 289-324; John P. Wright, Hume's Treatise of Human Nature: An Introduction, (Cambridge, 2009), 235-89. These authors have not dwelt on the anti-Augustinian aspects of Hume's philosophy, though they are central to Hume's rejection of the pride-focused accounts of Hobbes and Mandeville (more on this below). Moore's original arguments were a rejection of the position put forward in David Fate Norton, David Hume: Common Sense Moralist, Sceptical Metaphysician, (Princeon N.J., 1982). Norton, replied in Norton, 'The Question of Influence'. Whilst Norton was right in claiming that Hume stood opposed to the moral scepticism of Hobbes and Mandeville and asserted the 'reality' of moral distinctions, this is insufficient to establish a congruity between Hume and Hutcheson's projects - as the Moore, Robertson, Turco and Wright critique establishes. A recent dissenting voice on the matter of Hume's Epicureanism is James Harris, 'The Epicurean in Hume', in Epicurus in the Enlightenment, edited by Neven Leddy and Avi Lifchitz, (Oxford, 2009), who reads Hume as a modern sceptic breaking decisively with ancient traditions. The following seeks to cast doubt on Harris's approach, as well of that of Moore and Robertson.
} 
atmosphere in early eighteenth century Scotland was such that less able thinkers could see the outlines of the path Hume would later walk, even if they could only take faltering steps upon it.

My reading also depends, however, on it being granted that Campbell not only rejected Augustinianism, but that his philosophical system supplies sufficient evidence for reading him as engaged in a specifically Epicurean project - and this might be challenged. I conclude by considering some objections that might be made before reflecting on how we should approach the intellectual history of a revived tradition of Epicurean ideas. Although Campbell appeals to self-love and an underlying psychology of pleasure-seeking and pain-avoidance, which few would deny to be an essentially Epicurean tenet in eighteenth century thought, it might be claimed that this is not enough for him to be classed as an Epicurean thinker. Firstly, Campbell puts God at the centre of his account but a materialist Epicurean doctrine of atoms in void was previously interpreted as leading to the denial of the immortality of the soul, and to claim that if there were Gods they took no interest in human affairs. Secondly, Campbell's moral philosophy offers no vision of the sage transcending the vagaries of fortune by immunising himself to fear and anxiety via the cultivation of sustainable pleasures. Thirdly, and most conspicuously, Campbell asserts the natural sociability of man, and offers no variant of the Lucretian vision of the emergence of society from a 'state of nature' situation in which men are weak and vulnerable, grouping together thanks to various propulsions of self-interest rather than any appetite for society. Finally, whilst Campbell makes frequent appeal to classical sources, his preference is to cite the authority of Plato, Cicero and Seneca (amongst others), but not Lucretius, nor 
the account of ancient Epicureanism available from Diogenes Laërtius. Can Campbell be understood as an Epicurean thinker in light of these facts?

Campbell's Christianity is not so remarkable when we recall that in the previous century Gassendi had constructed an important synthesis between Epicurean materialism and Christian theology and moral philosophy. Certainly 'Epicure' was still deployed as a synonym for heterodoxy and atheism in the early eighteenth century, and indeed Campbell denounced the 'stupid notion' of the Epicureans that we should worship God only because he was wonderful and not because he rewards good actions. ${ }^{83}$ But taken on balance Campbell's work is best understood as being itself evidence that by the early eighteenth century Epicurean theses regarding motivation, psychology and morality could be straightforwardly detached from any underlying materialist assumptions and made compatible with a theistic outlook. ${ }^{84}$ By 1728 Epicurean moral theory was no necessary bar to Christianity, and vice-versa.

It is true that Campbell's work makes no appeal to ancient Epicurean notions of security from fear or anxiety, and he straightforwardly asserts the natural sociability of man. Can he really be an Epicurean thinker, even in specifically moral matters? It is worth noting that Campbell himself anticipated that he would be accused of being 'a Disciple of Epicurus, for being so prodigiously selfish, or so absolutely devoted to my own Pleasure and Happiness' ${ }^{85}$ But in any case, Campbell made relatively little attempt to deflect the accusations he suspected would be levelled at him, probably because he knew they were basically fair. Whether he be called a disciple of Epicurus 'and I know not what, perhaps a Destroyer of all Religion and Virtue', Campbell pressed what he saw

\footnotetext{
83 Campbell, Enquiry (1728), 315.

${ }^{84}$ Campbell, Enquiry (1728), 314-15.

85 Campbell, Enquiry (1728), 321; Enquiry (1733), 324.
} 
as the crucial point: 'But as all the World are agreed there must be some Motive or other that excites Rational Agents to the Pursuit of Moral Virtue, I would fain know what this Motive is, if it be not Self-Love, or Self-Interest' ${ }^{86}$ The psychological truism that we are driven by self-love meant that everyone would have to be an Epicurean if they were being truthful about the foundations of our psychology - a point he made openly in his 1733 edition, where he explicitly presented his moral philosophy as the respectable alternative to that of Hobbes, Mandeville and Spinoza. ${ }^{87}$

This perhaps explains Campbell's use of a variety of non-Epicurean classical sources. Campbell attempted to prove that at bottom everybody must be committed to the basic Epicurean thesis of pleasure-seeking and pain-avoidance, even if previous 'Disciples of Epicurus' had been mistaken to infer from this that moral distinctions were specious. His appeals to the ancients were intended to show that everybody was so committed, whilst attempting to simultaneously defuse and make reputable a basic Epicurean psychology and moral philosophy by claiming it was shared by the most respectable classical sources already. Rather than being evidence against Campbell's being an Epicurean outlook, his extensive appeals to classical non-Epicurean philosophy may be evidence for it.

As it turned out, Campbell's expectations of being labelled an Epicurean were well-founded. To the 1733 edition he added a new preface in which he addressed directly the accusation of being 'no better than the Disciples of Epicurus', levelled by none other than Hutcheson. Campbell hit back, demanding to know 'is a Thing false, because Epicurus maintain'd it? Or is a Thing true, because the late Earl of Shaftsbury (whose Principles Mr. Hutcheson professes to explain and defend) was pleased to

\footnotetext{
86 Campbell, Enquiry (1728), 230-1; Enquiry (1733), 324.

87 Campbell, Enquiry (1733), vi.
} 
declare for it?' 88 We should not 'startle at a truth because it is maintained by an Atheist, a Deist, or an Heretick'. And although it would cost him 'no great Pains to shew, that my Principles are not those of Epicurus', there was little point because truth could not be determined by appeal to names. Campbell would not 'affront my Reader in imagining, that in his Search after Truth, which he is to see with his own Eyes, he will pay a greater Regard to the Name of Shaftsbury, than to the Name Epicurus'. ${ }^{89}$

Campbell denied being an Epicurean but his denial was extremely relaxed, based merely on claiming that whether he shared views with Epicurus was beside the point. His denial is however of wider significance, and considering it helps us think more clearly about Campbell's intellectual project. For Campbell was arguably not 'an Epicurean' if that is understood as requiring strict adherence to particular tenets about the nature of God and the soul, the life of the wise man, human natural unsociability, or various other supposedly canonical requirements. ${ }^{90}$ But then, it may be that asking whether Campbell was 'an Epicurean' is not the most fruitful way to proceed. By the early eighteenth century it is unlikely any interesting thinker subscribed to all of whatever supposedly canonical tenets of Epicureanism might be listed. Then as now, interesting philosophical thought does not take the form of rigid subscription to calcified ideal-types of intellectual dogma, but evolves organically as thinkers look for ways to develop, combine and advance ideas. In Campbell's case this involved adopting what were usually considered to be - and recognised by his contemporaries as Epicurean tenets regarding motivation and psychology, using them to undergird a moral theory rejecting both Augustinianism and Stoicism. It becomes moot whether we

\footnotetext{
88 Campbell, Enquiry (1733), xiii-xiv.

${ }^{89}$ Campbell, Enquiry (1733), xiii.

90 This is the approach to Epicureanism in the history of ideas endorsed by Harris, 'The Epicurean in Hume'. It should be noted that this catalogue of requirements is itself highly problematic, ranging across features that are ancient or early modern in nature, but in many cases not both.
} 
should label Campbell 'an Epicurean'. What we can more usefully say is that Campbell drew upon Epicurean ideas. We can thereby locate him as part of a wider tradition of thinkers who likewise employed Epicurean ideas to varying, and sometimes opposed, effect. In the process our understanding of Epicureanism in the eighteenth century shifts from a static monolith of grouped dogmas to a range property, which individual thinkers adapted and drew upon depending on positions outside of this tradition to which they were also committed. This not only allows us to get a more subtle analytic grip on Campbell's project, but also of its relation to contemporary Enlightenment philosophies, and the development of moral thought in eighteenth century Scotland and beyond.

It might be objected, however, that by insisting we see Campbell as drawing upon Epicurean ideas rather than being 'an Epicurean', I have undercut the basis upon which the argument of this article has been made. ${ }^{91}$ If thinkers draw only upon particular ideas, how can they nonetheless be analysed in terms of 'Augustinianism', 'Epicureanism' or 'Stoicism', as I have done throughout? If those terms are to be retained, surely they must have definite content - in which case Campbell looks a marginal candidate for classification as Epicurean. But this objection is predicated on precisely the perspective we ought to resist when considering the deployment of Hellenistic thought in the early modern period; one that makes rigid categorisation primary, and is insufficiently responsive to the flexibility of authors who were engaged in live, on-going debates. To see this, a specific example is helpful, focusing first on Hume before returning to Campbell.

\footnotetext{
${ }^{91}$ I am here extremely grateful to an anonymous reviewer, whose incisive comments on this matter have helped me clarify my position.
} 
James Moore has analysed Hume's writings as part of an Epicurean tradition that centrally emphasises that man is naturally imbecilic like the animals, is in turn naturally unsociable due to his self-interest and lack of common affection, and can be rendered sociable only by artificial means. This pits Hume in opposition to Hutcheson, and puts him significantly closer to Mandeville than previous commentators have realised. ${ }^{92}$ John Robertson has followed Moore in this reading, identifying Hume as the inheritor (via Mandeville) of Pierre Bayle's belief that a society of atheists is possible, formed on the basis of self-interest rather than benevolence or religious cohesion. ${ }^{93}$

Moore and Roberson have enacted a major and welcome advance in our understanding of Hume, but we must be alert to the limitations of their approach. For both, Epicureanism entails commitment to natural unsociability, and thinkers can be grouped in an Epicurean tradition in large measure according to whether they subscribe to that tenet or not. But this is seriously problematic. First, it is insufficiently responsive to the complexity of the eighteenth century sociability debate. Hume in fact tells us that man is in some capacity naturally sociable due to his possession of sympathy, making him 'the creature of the universe, who has the most ardent desire of society, and is fitted for it by the most advantages'. ${ }^{94}$ Insofar as man encounters problems in maintaining company, this relates to large and lasting societies where the artifice of justice is required to regulate men's reasonable self-interest after the bonds of natural affection become too weak to control acquisitive behaviour. Human natural sociability is compromised by collective action problems relating to resource-management in large-

\footnotetext{
92 Moore, 'Hume and Hutcheson', 27-38, 47-51; 'The Eclectic Stoic', 140-4, 158.

93 Robertson, Case for the Enlightenment, 256-324.

94 Hume, Treatise, 234.
} 
scale groupings, and to which artifice is the remedy. ${ }^{95}$ By contrast, Mandeville had claimed (following Hobbes) that natural unsociability was a product of man's competitive pride. This made him mutually odious and physically dangerous to his peers, and he had to be controlled through mechanisms of fear. ${ }^{96}$ Hume denied that pride generated such dramatic consequences, or that fear was or could be the foundation of civil society, thus rejecting Mandeville's account (and by extension, Hobbes's). ${ }^{97}$ Accordingly Hume is best read not as a proponent of natural unsociability, but as Istvan Hont has suggested, as a theorist of 'commercial sociability'. ${ }^{98}$ Emphasising utility and controlled self-interest, commercial sociability is a conceptual middle route between pride-focused natural unsociability as exemplified in Hobbes and Mandeville, and those like Hutcheson who claimed that benevolence and natural affection rendered man naturally sociable. ${ }^{99}$ But in recognising this, we must call into question the approach that makes primary the claim that Hume is part of a definite Epicurean tradition, and which renders sociability a function of that (allegedly) prior commitment. Certainly, Hume drew upon Epicurean ideas: most obviously the foundation of human psychology in mechanisms of pleasure and pain, an emphasis on the conventional nature of some aspects of morality, and an emphasis on self-interest and gradualist developmental in explaining how men came to live in societies. But when examining the

\footnotetext{
95 That is, Hume's famous 'theory of justice' when seen in proper historical perspective is a sophisticated and important theory of commercial sociability.

${ }^{96}$ Mandeville's earliest direct, and most succinct, statement of natural unsociability is given in 'An Enquiry into the Origin of Moral Virtue', where fear is said to be used to control men by manipulating their pride and shame: Mandeville, Fable Vol. 1, 41-57. The central premise of this essay was later extensively refined in Fable Vol. 2, especially in the fifth and sixth dialogues, but Mandeville never abandoned its central contention. Before Mandeville, Hobbes had emphasised that fear of superior power was necessary in order to artificially socialize pride-driven competitive egoists: Hobbes, Leviathan, 75115, and also Thomas Hobbes, On the Citizen, edited by Michael Silverthorne and Richard Tuck (Cambridge, 1997), 21-31.

97 Hume, Treatise, 181-211, 227-55, 367-91.

${ }^{98}$ Hont, Jealousy of Trade, 40-1, 101-11, 160-3, 364-8, 476-7; 'Commercial Society and Political Theory', passim; 'The Language of Sociability and Commerce: Samuel Pufendorf and the Theoretical Foundations of the "Four Stages" Theory', in Jealousy of Trade, 159-84.

${ }^{99}$ Hont, Jealousy of Trade, 40-1.
} 
complexity of his thought on sociability, labelling him 'an Epicurean', rather than a theorist who drew upon Epicurean ideas, threatens to obscure as much as it reveals. More specifically, it gets the relationship between sociability and Epicureanism in eighteenth century debate, as well as their respective priority and importance, the wrong way around.

To see this better it is worth considering Hutcheson once more. In his 1730 inaugural lecture at the University of Glasgow, Hutcheson filed Pufendorf along with Hobbes as an 'Epicurean'. ${ }^{100}$ He did this because Pufendorf emphasised utility, and not benevolence, as the source of man's sociability. From Hutcheson's perspective this was both philosophically justified and rhetorically effective: utility was not a morally respectable basis for human sociability under benevolent divine providence, meaning Pufendorf degraded our essential moral natures and was appropriately stigmatised as a fellow traveller of the disreputable Hobbes. But from the historian's perspective this is not acceptable. Pufendorf was actually a theorist of commercial sociability, who denied that pride and glory-seeking necessarily generated the dramatic consequences Hobbes (and later, Mandeville) claimed, instead suggesting that reciprocal self-interest and the bonds of managed utility could be enough to establish large and lasting societies. ${ }^{101}$ Although Hutcheson's labelling of Pufendorf as an Epicurean made sense, philosophically and polemically, from within his own partisan perspective, we will fail to understand both the philosophies of his opponents, and the way in which 'Epicureanism' was a contestable and malleable range of ideas during the period, if we ourselves remain within Hutcheson's viewpoint.

\footnotetext{
${ }^{100}$ Francis Hutcheson, 'On the Natural Sociability of Mankind', in Logic, Metaphysics, and the Natural Sociability of Mankind, edited by James Moore and Michael Silverthorne, (Indianapolis, 2006), 191-216 (202); Hont, Jealousy of Trade, 39; Brooke, Philosophic Pride, 161. 101 Hont, 'The Language of Sociability', 166-72.
} 
Moving to the intellectual historian's viewpoint, if it is claimed that a thinker is not properly labelled Epicurean because he affirms natural sociability, the correct response is to ask why a rigid conception of Epicureanism is taken to be primary and authoritative in our conceptual ordering, and why it necessitates and determines affirmation of natural unsociability. As we have already noted, Hume, despite being claimed by Moore and Robertson as a major Epicurean thinker, in fact offered a highly nuanced position on the sociability question which is not accurately or perspicuously rendered as a theory of natural unsociability. The correct response to this realisation is not to conclude that therefore Hume wasn't really an Epicurean thinker, after all. (He clearly was, and Moore and Robertson have been right to identify as Epicurean central ideas in his moral and political philosophy.) The correct response is precisely to understand Epicureanism as I have suggested: as the appropriation and deployment of ranges of ideas in live and evolving debates, in this case exhibiting a complex relation to the debate over human sociability. The same response is thus deployed for Campbell as for Hume, but with the technical details appropriately altered: Campbell forthrightly asserted that man was naturally sociable, but did so whilst drawing upon Epicurean ideas such as the primacy of self-love and a fundamentally hedonistic psychology. Due to the centrality of these ideas in Campbell's account we are justified in classifying him as an Epicurean thinker. This remains so, even though Campbell engineered important philosophical disagreements with other thinkers we also classify as Epicurean due to their own, albeit different, deployment of Epicurean ideas. Ideas which were drawn from a range which was itself contested and subject to philosophical as well as polemical appropriation - as Hutcheson's treatment of Pufendorf reminds us. 
Although I have used sociability to illustrate the point, what has been said can be expanded to other contested areas of analysis we find in this period relating to the use of Hellenistic thought. In doing so we abandon the rigidity of our class of 'isms', using them as helpful, because flexible, expository devices for analysing thinkers and the ideas they drew upon. This has the advantage of paralleling, in both our historical recoveries and positive constructions, what the thinkers we are analysing were doing in their historical recoveries and positive constructions. It is also why I have not attempted to define Augustinianism, Epicureanism or Stoicism. We must instead use our informed judgement as to what these range properties can apply to, and how they can be accurately and informatively combined - just as the thinkers of the eighteenth century did in writing the works we are still trying to understand.

\section{Acknowledgements}

Istvan Hont has been an unfailing source of intellectual inspiration, direction and acceleration, whose guidance first led me to Campbell's work. John Robertson has likewise been an invaluable scholarly interlocutor and mentor, and without his encouragement, corrections and reflections this article would never have been published. Special thanks are owed to Christian Maurer for discussions of Campbell, and whose work has immeasurable improved my readings of that author. Christopher Brooke introduced me to intellectual history, and has been a permanent source of advice and comment on the eighteenth century and beyond. Jared Holley helped me to refine my understanding of eighteenth century Epicureanism. I am especially grateful to the editor, and to the comments of the anonymous referees, which were invaluable in clarifying my readings and position. 